\title{
The Identification of Outer Membrane Proteins and Flagella of Campylobacter jejuni
}

\author{
By D. G. NEWELL, ${ }^{*}$ H. MCBRIDE AND A. D. PEARSON \\ Public Health Laboratory, General Hospital, Tremona Road, Southampton SO9 $4 X Y$, UK
}

(Received 11 October 1983)

\begin{abstract}
The outer membrane proteins of five clinical isolates of Campylobacter jejuni were identified by ${ }^{125}$ I-surface labelling and SDS-PAGE of outer membrane preparations. All isolates expressed a major outer membrane protein of variable molecular weight (43000-46000: $43 \mathrm{~K}-46 \mathrm{~K})$. Several constant surface proteins were also identified including a $27 \mathrm{~K}$ protein which was surfaceexposed and acid-extractable but was not present in the outer membrane preparations. Isolated flagella comprised a major $62 \mathrm{~K}$ protein and a minor $87 \mathrm{~K}$ protein. Both proteins were absent in an aflagellate variant. The $62 \mathrm{~K}$ protein was immunoblotted and immunoprecipitated by rabbit anti-flagella antisera.
\end{abstract}

\section{INTRODUCTION}

The thermophilic, microaerophilic enteropathogen Campylobacter jejuni is the most frequently reported cause of human acute bacterial gastroenteritis in the UK (Skirrow, 1982). Campylobacter enteritis usually presents as acute diarrhoea, generally accompanied by abdominal pain and preceded by fever and malaise (Butzler \& Skirrow, 1979). The mechanism by which $C$. jejuni induces diarrhoea is unknown. Although there is no laboratory evidence for the production of an enterotoxin (Guerrant et al., 1978; Manninen et al., 1982) C. jejuni strains demonstrate invasive potential in vitro and in vivo (Manninen et al., 1982; Davidson \& Solomon, 1980).

Despite the prevalence of $C$. jejuni infections little is known about the surface structure of the organism. Such information is highly relevant to the study of pathogenic mechanisms as the successful establishment of an enteric infection is dependent on a number of surface components (virulence factors) which, for example, mediate attachment to the intestinal epithelial cells, preventing removal by gut motility or mucosal flow. This close association with the epithelial mucosa is a prerequisite to invasion or the effective action of enterotoxin (Giannella, 1981). Additionally, surface components may be immunogenic during infection thereby determining the host immune response to the infective agent.

This report describes the identification of the outer membrane proteins of five clinical isolates of $C$. jejuni by ${ }^{125} \mathrm{I}$-surface labelling and SDS-PAGE of outer membrane preparations. Additionally, flagella have been isolated and the flagellin protein identified using flagellate and aflagellate organisms with immunoblotting and radioimmunoprecipitation techniques.

\section{METHODS}

Bacterial strains. The $C$. jejuni isolates used in this study are described in Table 1. All strains, except 81116 , were from sporadic cases of campylobacter enteritis. Strain 81116 was isolated from a patient involved in an outbreak of campylobacter enteritis at a school (Palmer et al., 1983). Strains were biotyped as described by Skirrow \& Benjamin (1980) and kindly serotyped by Dr J. Penner using the passive haemagglutination technique (Penner \& Hennessy, 1980).

Faecal isolates were purified on antibiotic selective medium at $42{ }^{\circ} \mathrm{C}$ (Skirrow, 1977) under microaerophilic conditions. Purified isolates were subcultured on blood agar containing $5 \%(\mathrm{v} / \mathrm{v})$ defibrinated horse blood and $2 \%$ $(\mathrm{w} / \mathrm{v})$ agar and stored in $10 \%(\mathrm{v} / \mathrm{v})$ glycerol in $1 \%(\mathrm{w} / \mathrm{v})$ proteose peptone, in liquid nitrogen. For outer membrane 


\section{Table 1. Strains of C. jejuni/coli investigated}

\begin{tabular}{lllc} 
Strain & Source & \multicolumn{1}{c}{ Biotype } & Serotype* \\
81116 & Human & C. jejuni II & 6 \\
63923 & Human & C. jejuni I & 2 \\
33817 & Human & C. jejuni II & UT \\
68869 & Human & C. jejuni I & UT \\
51180 & Human & C. jejuni I & 30
\end{tabular}

* UT, untypable.

preparations isolates were cultured on blood-free agar $(2 \%, \mathrm{w} / \mathrm{v}$, agar containing $0.4 \%, \mathrm{v} / \mathrm{v}$, campylobacter growth supplement; Oxoid). For flagella and acid extract preparations isolates were cultured in nutrient broth: $2 \cdot 5 \%$ (w/v) nutrient broth base no. 2 (Oxoid) $; 0.5 \%(\mathrm{w} / \mathrm{v})$ yeast extract; $0.01 \%(\mathrm{w} / \mathrm{v})$ cysteine $; 0.08 \%(\mathrm{w} / \mathrm{v})$ potassium nitrate and $0.4 \%(\mathrm{v} / \mathrm{v})$ campylobacter growth supplement.

An aflagellate variant $\left(81116 \mathrm{Fla}^{-}\right)$was isolated from the flagellate wild-type $\left(81116 \mathrm{Fla}^{+}\right)$by enrichment of non-motile organisms in semi-solid nutrient gelatin medium : $1 \%(\mathrm{w} / \mathrm{v})$ peptone $; 0.33 \%(\mathrm{w} / \mathrm{v})$ yeast extract $; 0.5 \%$ $(\mathrm{w} / \mathrm{v})$ sodium chloride; $0.8 \%(\mathrm{w} / \mathrm{v})$ gelatin; $0.75 \%(\mathrm{w} / \mathrm{v})$ agar. Non-motile colonies were identified on nutrient gelatin medium containing $1 \%(\mathrm{w} / \mathrm{v})$ agar. The variant was cloned six times to confirm its stability.

Antisera. Rabbits were immunized intramuscularly with formalin-treated $(0.3 \%$ formalin) bacterial suspension $\left(0.5 \mathrm{ml}, A_{540}=10 \cdot 0\right)$, outer membrane preparation $(20 \mu \mathrm{g}$ protein $)$ or purified flagella $(10 \mu \mathrm{g}$ protein $)$ in Freund's complete adjuvant. The rabbits were boosted at $14 \mathrm{~d}$ intervals with a series of subcutaneous injections of the same antigen in Freund's incomplete adjuvant.

${ }^{125}$ I-surface labelling of whole bacteria. Campylobacter jejuni strains, grown on blood-free agar, were washed twice by centrifugation $\left(5000 \mathrm{~g}\right.$ for $15 \mathrm{~min}$ at $\left.4{ }^{\circ} \mathrm{C}\right)$ in phosphate-buffered saline [PBS: $0.8 \%(\mathrm{w} / \mathrm{v})$ sodium chloride $; 0.02 \%(\mathrm{w} / \mathrm{v})$ potassium chloride; $0.115 \%(\mathrm{w} / \mathrm{v})$ disodium hydrogen phosphate; $0.02 \%(\mathrm{w} / \mathrm{v})$ potassium dihydrogen phosphate] with $0.01 \%(\mathrm{w} / \mathrm{v})$ calcium chloride and $0.01 \%(\mathrm{w} / \mathrm{v})$ magnesium chloride. Bacteria were ${ }^{125} \mathrm{I}$-surface labelled using the lactoperoxidase method (Marchalonis et al., 1971). Briefly, $1 \times 10^{9}$ c.f.u. in $500 \mu \mathrm{l}$ PBS, with calcium and magnesium, were mixed with $5 \mu \mathrm{lof}$ a $1 \mathrm{mg} \mathrm{ml}{ }^{-1}$ solution of lactoperoxidase (Sigma) and $50 \mu \mathrm{Ci}(1850 \mathrm{kBq}) \mathrm{Na}^{125} \mathrm{I}$ (Amersham). Portions $(50 \mu \mathrm{l})$ of $0.02 \mathrm{M}$-hydrogen peroxide were added at $2.5 \mathrm{~min}$ intervals and the reaction was stopped after $10 \mathrm{~min}$ by the addition of $10 \mathrm{ml} 5 \mathrm{~mm}$-cysteine. The specific activity of the ${ }^{125}$ I-labelled bacteria was approximately $5 \mu \mathrm{Ci} \mathrm{mg}^{-1}$.

For radioimmunoprecipitation experiments bacteria were surface-labelled using 1,3,4,6-tetrachloro-3 $\alpha, 6 \alpha$ diphenyl glycouril (Iodogen; Pierce \& Warriner, Chester, UK) by the technique of Swanson (1981). Approximately $3 \times 10^{8}$ c.f.u. in $40 \mu \mathrm{l}$ PBS were incubated with $5 \mu \mathrm{l}$ of $10^{-5} \mathrm{M}$-potassium iodide and $500 \mu \mathrm{Ci}$ $\mathrm{Na}^{125} \mathrm{I}$ in a small glass tube coated with $10 \mu \mathrm{g}$ Iodogen for $10 \mathrm{~min}$ at $20^{\circ} \mathrm{C}$. ${ }^{125} \mathrm{I}$-labelled bacteria (specific activity approximately $1 \mu \mathrm{Ci} \mu \mathrm{g}^{-1}$ ) were washed three times in PBS and solubilized for radioimmunoprecipitation experiments in $0.1 \%(\mathrm{w} / \mathrm{v})$ SDS, $3.0 \%$ (w/v) Empigen BB (Albright \& Wilson, Whitehaven, UK) in PBS at $40{ }^{\circ} \mathrm{C}$ for $1 \mathrm{~h}$.

Preparation of spheroplast-derived outer membranes. Nutrient broth cultures were harvested by centrifugation $\left(5000 \mathrm{~g}, 20 \mathrm{~min}\right.$ ) and resuspended in $0.75 \mathrm{M}$-sucrose, $10 \mathrm{mM}$ - Tris $/ \mathrm{HCl}, \mathrm{pH} 7.8$, at $4{ }^{\circ} \mathrm{C}$ to give an $A_{540}$ of 10.0 . Lysozyme was added to the suspension to give a final concentration of $0.2 \mathrm{mg} \mathrm{ml}^{-1}$ followed by the slow addition of two volumes of $4.5 \mathrm{mM}$-EDTA, pH 7.5 , at $4{ }^{\circ} \mathrm{C}$. After $2 \mathrm{~h}$ of gentle stirring at $20^{\circ} \mathrm{C}, 80-90 \%$ of the bacteria had formed spheroplasts. Spheroplast lysis and membrane separation were initiated by the addition of the following agents to the stated final concentrations: $0.05 \%(w / v)$ Brij 58 (Sigma); 14 units DNAase I ml ${ }^{-1}$ (Sigma); 15 units RNAase A ml ${ }^{-1}$ (Sigma) and $3 \mathrm{~mm}$-magnesium chloride. After incubation for $20 \mathrm{~min}$ at $37^{\circ} \mathrm{C}$ unlysed cells were removed by centrifugation $(5000 \mathrm{~g}, 30 \mathrm{~min})$ and the membrane fraction was recovered from the supernatant solution $(100000 \mathrm{~g}, 2 \mathrm{~h})$. The membrane pellet was washed in $3 \mathrm{mM}$-EDTA, $10 \mathrm{~mm}$-Tris/acetate buffer, $\mathrm{pH} 7.5$, then layered on a $20-55 \%(\mathrm{w} / \mathrm{w})$ sucrose gradient containing $5 \mathrm{~mm}$-EDTA and centrifuged at $90000 \mathrm{~g}$ for $18 \mathrm{~h}$. Fractions were collected, analysed for protein and pooled as appropriate. Succinate dehydrogenase activity was determined by the reduction of 2,6-dichlorophenol indophenol coupled to phenazine methosulphate (Arrigoni \& Singer, 1962; Churchward \& Holland, 1976) and lipopolysaccharide estimated by the thiobarbituric acid assay for ketodeoxyoctonate (Waravdekar \& Saslaw, 1969).

Preparation of Sarkosyl-insoluble outer membranes. Campylobacter jejuni was harvested as previously described, washed in $0.05 \mathrm{M}$-Tris $/ \mathrm{HCl}$ buffer, $\mathrm{pH} 7.5$, at $4{ }^{\circ} \mathrm{C}$ and resuspended in the same buffer to give an $A_{540}$ of 1.0 . The suspension was sonicated $(4 \times 30 \mathrm{~s}$ periods with $30 \mathrm{~s}$ cooling intervals) at $10 \mu \mathrm{A}$ (Soniprep 150; MSE). Cellular debris was removed by centrifugation at $5000 \mathrm{~g}$ for $20 \mathrm{~min}$ and the crude membranes were recovered from the supernatant $(100000 \mathrm{~g}, 60 \mathrm{~min})$. The membrane pellet was suspended in $1 \%(\mathrm{w} / \mathrm{v}) \mathrm{N}$-lauroylsarcosine sodium salt (Sarkosyl; Sigma) in $7 \mathrm{~mm}$-EDTA, pH 7.6 , at $37^{\circ} \mathrm{C}$ for $20 \mathrm{~min}$ to give a protein to detergent ratio of approximately $1: 4(\mathrm{w} / \mathrm{w})$ (Filip et al., 1973). The suspension was centrifuged at $100000 \mathrm{~g}$ for $2 \mathrm{~h}$ and the pellet re-extracted with detergent as above. The extracted membranes were washed three times in $0.05 \mathrm{M}$-Tris/ $\mathrm{HCl}$ buffer, $\mathrm{pH} 7.5$, and stored at $-20^{\circ} \mathrm{C}$. 
Preparation of acid extract. An acid extract was prepared from $C$. jejuni 81116 according to the method of McCoy et al. (1975). Bacteria (4.0 g wet weight) were washed twice in distilled water and resuspended in $100 \mathrm{ml}$ $0 \cdot 2 \mathrm{M}$-glycine/ $\mathrm{HCl}$ buffer, $\mathrm{pH} 2 \cdot 2$. The suspension was stirred for $15 \mathrm{~min}$ at $20^{\circ} \mathrm{C}$ then centrifuged to remove the cells $(10000 \mathrm{~g}, 20 \mathrm{~min})$. The supernatant was neutralized and dialysed against distilled water.

Preparation of flagella. Bacteria $(5.5 \mathrm{~g})$ were resuspended in $250 \mathrm{ml}$ PBS with calcium and magnesium at $4{ }^{\circ} \mathrm{C}$ and homogenized in a laboratory blender fitted with disintegrating and axial flow heads (Silverson Machines, Chesham, UK) for three periods of $1 \mathrm{~min}$ with $30 \mathrm{~s}$ cooling intervals. Isolation of the flagella was achieved by centrifugation at $5000 \mathrm{~g}$ for $30 \mathrm{~min}$ to remove the cellular debris, followed by centrifugation of the supernatant solution at $100000 \mathrm{~g}$ for $2 \mathrm{~h}$. These centrifugation steps were repeated twice. The purity of the flagella was monitored by electron microscopy of negative-stained preparations.

${ }^{125}$ I-labelling of flagella. This was done according to the method of Der-Balain (1980). Briefly, $120 \mu \mathrm{g}$ of flagella in $0.3 \mathrm{M}$-Tris/ $\mathrm{HCl}$ buffer, $\mathrm{pH} 8.5$, were added to $500 \mu \mathrm{Ci}(18500 \mathrm{kBq})$ methyl 3,5-di[ $\left.{ }^{125} \mathrm{I}\right]$ iodohydroxybenzimidate (Amersham). The mixture was gently stirred for $48 \mathrm{~h}$ at $37^{\circ} \mathrm{C}$. The flagella were dialysed against PBS and resuspended in $3 \%(\mathrm{v} / \mathrm{v})$ Empigen BB, $0.1 \%(\mathrm{w} / \mathrm{v})$ SDS in PBS. The specific activity was approximately $2 \mu \mathrm{Ci} \mathrm{mg}{ }^{-1}$.

SDS-PAGE. A $10-25 \%(\mathrm{w} / \mathrm{v})$ linear gradient SDS-PAGE system was used (Lambden et al., 1979). Protein bands were stained with Kenacid blue $\mathbf{R}(\mathrm{BDH})$. The protein molecular weight markers were trypsin, ovalbumin, bovine serum albumin (BSA) and lysozyme.

Radioimmunoprecipitation. ${ }^{125} \mathrm{I}$-labelled material was centrifuged at $10000 \mathrm{~g}$ for $1.5 \mathrm{~h}$ to remove any insoluble material and $80 \mu \mathrm{l}$ samples (approximately 40000 c.p.s. of ${ }^{125} \mathrm{I}$-solubilized bacteria or 2000 c.p.s. of ${ }^{125} \mathrm{I}$-flagella) were mixed with $40 \mu \mathrm{l}$ of a $1: 2$ dilution of rabbit sera for $20 \mathrm{~min}$ at $4{ }^{\circ} \mathrm{C}$. Then $40 \mu 1$ swollen protein A covalently coupled to Sepharose CL-4B (Sigma) swollen in $100 \mu 1$ PBS containing $1 \mathrm{mg}$ BSA was added to each sample. The samples were incubated at $20^{\circ} \mathrm{C}$ for $1 \mathrm{~h}$ with mixing and the Sepharose beads were then washed five times in PBS.

Electroimmunoblotting. SDS-PAGE gels of strains $81116 \mathrm{Fla}^{+}$and $81116 \mathrm{Fla}^{-}$and of purified flagella were electroblotted on to nitrocellulose in $3.0 \mathrm{~g}$ Tris $1^{-1}, 14.4 \mathrm{~g}$ glycine $1^{-1}$ and $20 \%(\mathrm{v} / \mathrm{v})$ methanol at $60 \mathrm{~V}$ for $5 \mathrm{~h}$. Nonspecific protein binding was eliminated by incubation in $3 \%(\mathrm{w} / \mathrm{v}) \mathrm{BSA}$ in $10 \mathrm{mM}$-Tris, $0.9 \%(\mathrm{w} / \mathrm{v})$ sodium chloride, $\mathrm{pH} 7 \cdot 4$, for $2 \mathrm{~h}$ at $37^{\circ} \mathrm{C}$. The blots were then incubated with 1:100 rabbit antisera diluted in dilution

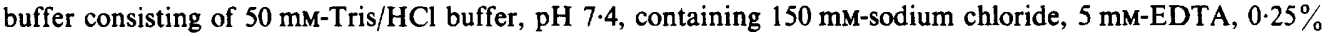
$(\mathrm{w} / \mathrm{v})$ gelatin and $0.05 \%(\mathrm{v} / \mathrm{v})$ Nonidet P-40 (Sigma), for $2 \mathrm{~h}$ at $37^{\circ} \mathrm{C}$. After a brief wash in PBS the blots were incubated $\left(2 \mathrm{~h}, 37^{\circ} \mathrm{C}\right.$ ) with 1:1000 (in dilution buffer) peroxidase-conjugated goat anti-rabbit IgG (Miles Research Laboratories, Slough, UK) and the unbound protein was removed by extensive washing [500 mM-

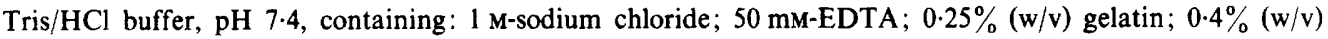
sodium lauroylsarcosine]. Peroxidase was detected by incubation with $2.5 \mathrm{mg} o$-dianisidine in $100 \mathrm{ml} 10 \mathrm{~mm}$ -

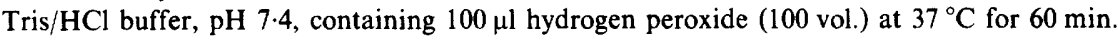

\section{RESULTS}

\section{Identification of the outer membrane proteins of $C$. jejuni}

The surface-exposed outer membrane proteins of five $C$. jejuni isolates were ${ }^{125} \mathrm{I}$-labelled using the lactoperoxidase technique (Fig. 1). A major polypeptide of variable molecular weight $(43000-46000: 43 \mathrm{~K}-46 \mathrm{~K})$ was seen in all isolates. Four minor constant proteins with molecular weights of $72 \mathrm{~K}, 64 \mathrm{~K}, 35 \mathrm{~K}$ and $27 \mathrm{~K}$ and a minor variable protein $(70 \mathrm{~K}-75 \mathrm{~K})$ were also ${ }^{125} \mathrm{I}-$ labelled. Iodination of surface proteins using the Iodogen technique instead of lactoperoxidase produced a similar pattern of ${ }^{125} \mathrm{I}$-labelled proteins but an additional protein of $27.5 \mathrm{~K}$ was observed. The isolation of outer membranes was considered necessary for further characterization of these surface proteins. Initially a spheroplasting technique was used to prepare outer membranes. Sucrose gradient separation of the membranous material from the lysed spheroplasts gave three protein peaks $\left(\rho=1.17,1.20\right.$ and $\left.1.28 \mathrm{~g} \mathrm{ml}^{-1}\right)$ the fractions of which were pooled (P1, P2 and $\mathrm{P} 3$ respectively). $\mathrm{P} 1$ contained $58 \%$ of the succinate dehydrogenase activity and $20.9 \%$ of the LPS, whilst P3 contained $20 \%$ of the succinate dehydrogenase activity and $49 \%$ of the LPS. The SDS-PAGE profiles of these pooled fractions are shown in Fig. 2(a). P3 contained a restricted number of proteins with enhanced concentrations of the major variable protein $(43 \mathrm{~K}-46 \mathrm{~K})$ and a $62 \mathrm{~K}$ protein. However, $\mathrm{P} 3$ also contained several minor protein bands which suggested some contamination with cytoplasmic membrane material. Outer membranes were therefore prepared by Sarkosyl extraction of crude membrane preparations. The membranous material retained after this extraction procedure had fewer minor proteins than fraction P3 (Fig. 2a) but otherwise had a similar protein profile. This Sarkosyl technique was used to prepare outer membranes from the four other $C$. jejuni isolates (Fig. $2 b$ ). The variable 


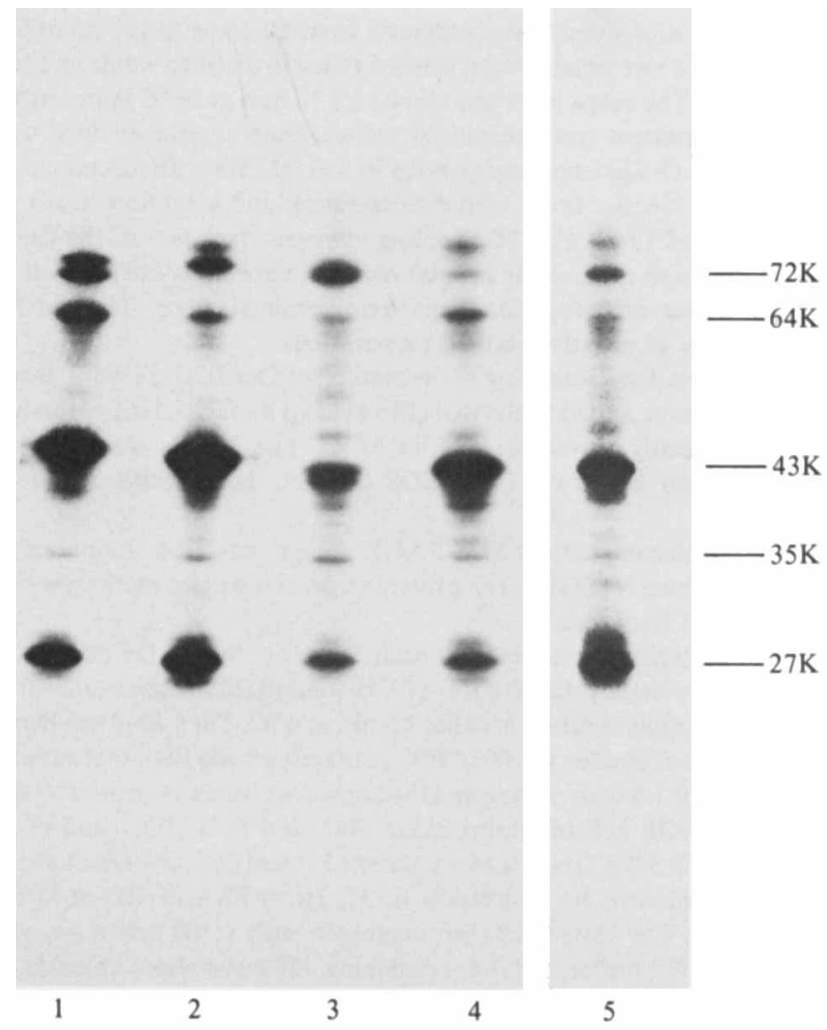

Fig. 1. Autoradiograph of ${ }^{125} I$-surface-labelled $C$. jejuni isolates: (1), strain 51180 ; (2), strain 68869 ; (3), strain 63923; (4), strain $33817 ;(5)$, strain 81116.

$43 \mathrm{~K}-46 \mathrm{~K}$ protein was the main component of all the outer membranes and will henceforth be termed the major outer membrane protein. Several constant outer membrane proteins were observed including a greatly enhanced protein with a molecular weight of $62 \mathrm{~K}$ and minor constant proteins of $35 \mathrm{~K}$ and $87 \mathrm{~K}$. Derivatization of the outer membrane material at $37^{\circ} \mathrm{C}$ for $2 \mathrm{~h}$, instead of $100^{\circ} \mathrm{C}$ for $5 \mathrm{~min}$, caused an apparent reduction in molecular weight of the major outer membrane protein, the $35 \mathrm{~K}$ protein and several other minor proteins and an increase in molecular weight of the $87 \mathrm{~K}$ protein.

\section{Isolation and identification of C. jejuni flagella}

Preparations of purified flagella contained a major diffuse protein band with a molecular weight of $62 \mathrm{~K}$ (Fig. $2 a$ ). This protein corresponded with the $62 \mathrm{~K}$ protein in the outer membrane preparations. Additionally a minor contaminating $87 \mathrm{~K}$ protein was observed. Both of these proteins were absent in outer membrane preparations from an aflagellate variant. The $62 \mathrm{~K}$ but not the $87 \mathrm{~K}$ protein was a significant component of the acid-extractable material from whole bacteria which contained three other major proteins with molecular weights of $38 \mathrm{~K}, 27 \mathrm{~K}$ and 25K (Fig. 2a).

Rabbit antisera directed against the flagellate wild-type, an aflagellate variant and purified flagella were used to confirm the identity of the flagella protein, using immunoblotting techniques. A $62 \mathrm{~K}$ protein was detected by antisera directed against the flagellate organism or purified flagella but not by antisera directed against the aflagellate variant (Fig. 3). However, some labelling of the $62 \mathrm{~K}$ protein in the aflagellate variant was observed with antiflagella antisera. 

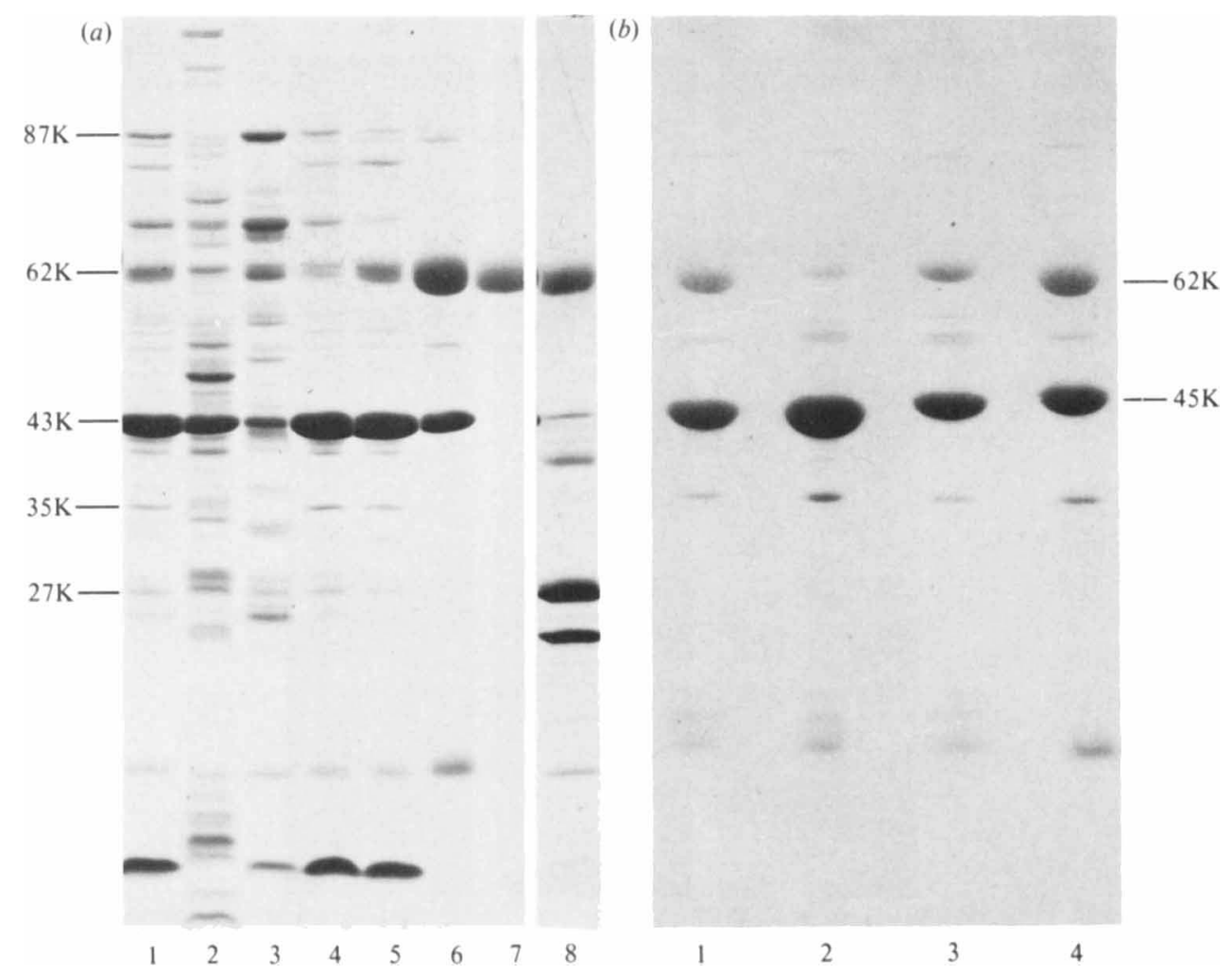

Fig. 2. (a) SDS-PAGE of $C$. jejuni strain 81116: (1), whole cell protein profile; (2), crude membrane preparation; (3), sucrose gradient fraction $P_{1}$ (cytoplasmic membrane); (4), sucrose gradient fraction $\mathrm{P}_{2} ;(5)$, sucrose gradient fraction $\mathrm{P}_{3}$ (outer membrane); (6), Sarkosyl-insoluble outer membrane preparation; (7), isolated flagella; (8), acid-extractable material. (b) SDS-PAGE of Sarkosyl-insoluble outer membrane preparations from $C$. jejuni isolates: (1), strain 33817 ; (2), strain 63923 ; (3), strain 68869 ; (4), strain 51180.

Attempts to ${ }^{125}$ I-label undissociated flagella using Iodogen or lactoperoxidase were unsuccessful. However, when purified flagella were reacted with methyl $3,5-\mathrm{di}\left[{ }^{125} \mathrm{I}\right]$ iodohydroxybenzimidate a single ${ }^{125} \mathrm{I}$-labelled protein band of $62 \mathrm{~K}$ was obtained. This protein was immunoprecipitated with rabbit antisera directed against purified flagella or the flagellate wildtype but not by control rabbit serum. A small amount of this $62 \mathrm{~K}$ was also precipitated by antisera directed against the aflagellate variant. In some immunoprecipitation experiments a small amount of the $43 \mathrm{~K}$ protein was also precipitated.

\section{DISCUSSION}

The outer membrane proteins of five clinical isolates of $C$. jejuni have been identified by ${ }^{125} \mathrm{I}$ surface labelling and by the SDS-PAGE of outer membrane preparations isolated by sucrose gradient centrifugation of spheroplasts and Sarkosyl extraction of crude membranes. A major protein, of variable molecular weight $(43 \mathrm{~K}-46 \mathrm{~K})$, was consistently observed in the outer membrane preparations of all isolates. Logan \& Trust (1982) found a similar protein (band e) to be characteristic of type strains and wild-type isolates of $C$. jejuni and $C$. coli and suggested that this is a porin or matrix protein. Previous antibody protection studies on the major outer membrane proteins of C. fetus (McCoy et al., 1976) suggested that these proteins were unexposed. In contrast, ${ }^{125} \mathrm{I}$-surface labelling studies indicate that the major outer membrane protein of $C$. jejuni is surface-exposed. 
(a)

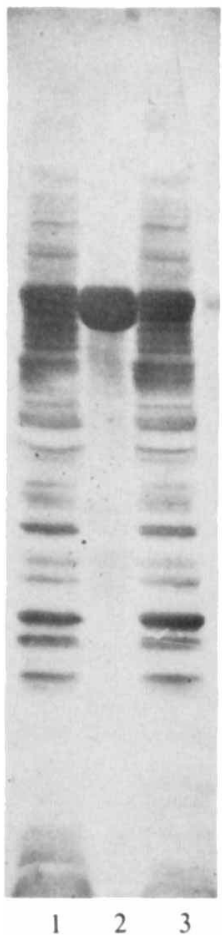

(b)

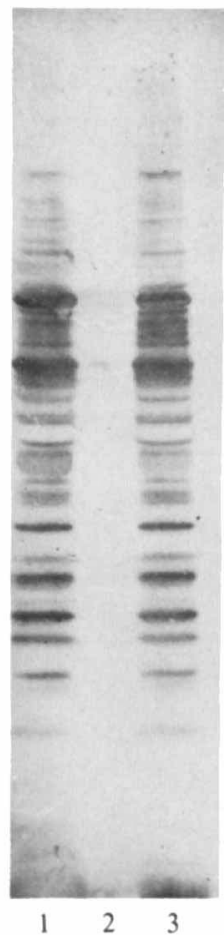

(c)

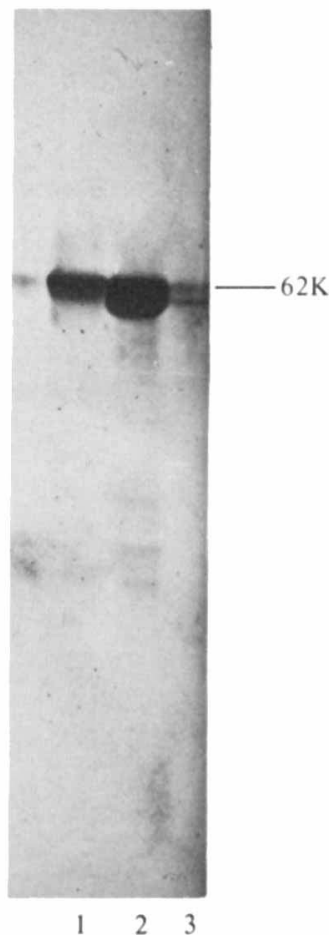

Fig. 3. Electroimmunoblots of (1) strain $81116 \mathrm{Fla}^{+}$, (2) isolated flagella and (3) strain $81116 \mathrm{Fla}^{-}$ incubated with rabbit antisera directed against $(a)$ strain $81116 \mathrm{Fla}^{+},(b)$ strain $81116 \mathrm{Fla}^{-}$and $(c)$ flagella.

A surface-exposed and heat-modifiable minor outer membrane protein had a constant molecular weight of $35 \mathrm{~K}$ in the five $C$. jejuni strains investigated. This protein was absent in outer membrane preparations from three $C$. coli strains which expressed a $41 \mathrm{~K}$ protein of similar properties (unpublished data). The relationship of these two proteins to species differences between $C$. jejuni and C. coli (Owen \& Leaper, 1981; Belland \& Trust, 1982; Skirrow \& Benjamin, 1980) is under investigation.

A $27 \mathrm{~K}$ protein was ${ }^{125} \mathrm{I}$-surface-labelled in all the isolates investigated. This protein was not, however, detected by SDS-PAGE in the outer membranes prepared by either technique, but was present in an acid-extractable material. Using the same extraction conditions McCoy et al. (1975) isolated an antiphagocytic microcapsular component from the surface of $C$. fetus. However, neither conventional transmission electron microscopy nor staining techniques using colloidal thorium, ruthenium red or India ink indicate the presence of a capsular structure on $C$. jejuni (unpublished data).

Purified flagella contained a major $62 \mathrm{~K}$ and a minor $87 \mathrm{~K}$ protein. Both proteins were absent in outer membrane preparations from an aflagellate variant. Although $62 \mathrm{~K}$ is a high molecular weight for flagellin it is not inconsistent with the larger flagellins of some Escherichia coli and Salmonella strains (Lawn, 1977; Kondah \& Hotani, 1974). The identity of $C$. jejuni flagellin as the $62 \mathrm{~K}$ protein was confirmed using immunoblotting and radioimmunoprecipitation techniques with rabbit antisera directed against purified flagella, the flagellate wild-type strain or an aflagellate variant. Small amounts of flagellin were detected in the aflagellate variant by immunoblotting and immunoprecipitation suggesting that the variant can synthesize flagellin but not assemble flagella. Although amino acid analysis of purified flagella indicates the presence of tyrosine and histidine (unpublished data), intact flagella could not be ${ }^{125} \mathrm{I}$-labelled 
using the lactoperoxidase or Iodogen techniques, suggesting an inaccessibility of these residues. However, flagella could be ${ }^{125} \mathrm{I}$-iodinated by incubation with methyl 3,5-di[ $\left[{ }^{125} \mathrm{I}\right]$ iodohydroxybenzimidate. This iodination technique produced radio-labelled flagella suitable for radioimmunoprecipitation experiments.

At present little is known about the antigenicity of $C$. jejuni surface components. Recent studies have shown that LPS (Walder \& Foresgen, 1982) and the acid-extractable surface components (Rautelin \& Kosunen, 1983) are major surface antigens which may be relevant in serotyping and serodiagnosis. Preliminary investigations (Newell, 1983) indicate that the major outer membrane protein, a $27 \mathrm{~K}$ surface protein and flagella are also immunogenic during naturally acquired human campylobacter enteritis. Furthermore, the antibodies produced against these proteins are cross-reactive with other serotypes of $C$. jejuni. Further work is in progress to investigate the importance of these proteins in the pathogenesis of, and the immune response to, $C$. jejuni infections.

We thank Dr John Heckels and Professor Peter Watt for many helpful discussions.

\section{REFERENCES}

ARrigoni, O. \& Singer, T. P. (1962). Limitations of the phenazine methosulphate assay for succinic and related dehydrogenases. Nature, London 193, 12561258 .

Belland, R. J. \& Trust, T. J. (1982). Deoxyribonucleic acid sequence relatedness between thermophilic members of the genus Campylobacter. Journal of General Microbiology 128, 2515-2522.

Butzler, J. P. \& Skirrow, M. B. (1979). Campylobacter enteritis. Clinics in Gastroenterology 8, 737765 .

Churchward, G. G. \& Holland, I. B. (1976). Envelope synthesis during the cell cycle in Escherichia coli B/r. Journal of Molecular Biology 105, 245261.

Davidson, J. A. \& Solomon, J. B. (1980). Onset of resistance to pathogenic strains of Campylobacter fetus subspecies jejuni in the chick embryo. In Aspects of Developmental and Comparative Immunology - I, pp. 289-294. Edited by J. B. Solomon. Oxford: Pergamon Press.

Der-Balian, G. P. (1980). Imidoester iodination of immunoglobulins to high specific activity. Analytical Biochemistry 106, 411-416.

Filip, C., Fletcher, G., WulfF, J. F. \& Earhart, C. F. (1973). Solubilization of the cytoplasmic membrane of Escherichia coli by the ionic detergent sodium lauryl sarcosinate. Journal of Bacteriology $115,717-722$

Giannella, R. A. (1981). Pathogenesis of acute bacterial diarrhoeal disorders. Annual Review of Medicine 32, 341-357.

Guerrant, R. L., Lahita, R. G., Winn, W. C. \& ROBERTS, R. B. (1978). Campylobacteriosis in man: pathogenic mechanisms and review of 91 bloodstream infections. American Journal of Medicine 65 , 584-592.

KondaH, H. \& Hotani, H. (1974). Flagellin from Escherichia coli $\mathrm{K} / 2$. Polymerization and molecular weight in comparison with Salmonella flagellins. Biochimica et biophysica acta 336, 117-139.

LAMBdEN, P. R., HeCkels, J. E., JAMES, L. T. \& WATTS, P. J. (1979). Variations in surface protein composition associated with virulence properties in opacity types of Neisseria gonorrhoeae. Journal of General Microbiology 114, 305-312.

LAWN, A. M. (1977). Comparison of the flagellins from different flagellar morphotypes of Escherichia coli. Journal of General Microbiology 101, 112-130.

Logan, S. M. \& TRUST, T. J. (1982). Outer membrane characteristics of Campylobacter jejuni. Infection and Immunity 38, 898-906.

Manninen, K. I., Prescott, J. F. \& Dohoo, I. R. (1982). Pathogenicity of Campylobacter jejuni isolates from animals and humans. Infection and Immunity 38, 46-52.

Marchalonis, J. J., CONE, R. E. \& SANTER, V. (1971). A probe for accessible surface proteins of normal and neoplastic lymphocytes. Biochemical Journal 124, 921-927.

McCoy, E. C., Doyle, D., Burda, K., Corbeil, L. B. \& WINTER, A. J. (1975). Superficial antigens of Campylobacter (Vibrio) fetus: characterisation of an antiphagocytic component. Infection and Immunity 11, 517-525.

McCoy, E. C., Wiltberger, H. A. \& Winter, A. J. (1976). Major outer membrane protein of Campylobacter fetus: physical and immunological characterisation. Infection and Immunity 13, 12581265.

Newell, D. G. (1983). The surface protein antigens, including flagella of Campylobacter. jejuni. In Campylobacter II, pp. 66. Edited by A. D. Pearson, M. B. Skirrow, B. Rowe, J. R. Davis \& D. M. Jones. London: P.H.L.S.

OWEN, R. J. \& LeAPER, S. (1981). Base composition, size and nucleotide sequence similarities of genome deoxyribonucleic acids from species of the genus Campylobacter. FEMS Microbiology Letters 12, 395400.

Palmer, S. R., Gully, P. R., White, J. M., Pearson, A. D., Suckling, W. G., Jones, D. M., Rawes, J. C. L. \& Penner, J. L. (1983). Water-borne outbreak of campylobacter gastroenteritis. Lancet i, 287-290.

Penner, J. L. \& Hennessy, J. N. (1980). Passive haemagglutination technique for serotyping Campylobacter fetus subspecies jejuni on the basis of 
soluble heat-stable antigens. Journal of Clinical Microbiology 12, 732-737.

Rautelin, H. \& Kosunen, T. U. (1983). An acid extract as a common antigen in Campylobacter coli and Campylobacter jejuni strains. Journal of Clinical Microbiology, 17, 700-701.

Skirrow, M. B. (1977). Campylobacter enteritis: a 'new' disease. British Medical Journal 2, 9-11.

Skirrow, M. B. (1982). Campylobacter enteritis - the first five years. Journal of Hygiene 89, 175-184.

SkirRow, M. B. \& Benjamin, J. (1980). Differentiation of enteropathogenic campylobacter. Journal of Clinical Pathology 33, 1122.

Skirrow, M. B. \& BenJamin, J. (1982). The classification of 'thermophilic' campylobacters and their distribution in man and domestic animals. In
Campylobacter: Epidemiology, Pathogenesis and Biochemistry, pp. 40-44. Edited by D. G. Newell. Lancaster: MTP Press.

Swanson, J. (1981). Surface exposed protein antigens of the gonococcal outer membrane. Infection and Immunity 34, 804-816.

Walder, M. \& Forsgren, A. (1982). Enzyme-linked immunosorbent assay (ELISA) for antibodies against Campylobacter jejuni and its clinical application. Acta pathologica, microbiologica et immunologica scandinavica 90, 423-433.

Waravdekar, V. S. \& Saslaw, L. D. (1959). A sensitive colorimetric method for the estimation of 2deoxy sugars with the use of the malonaldehyde thiobarbituric acid reaction. Journal of Biological Chemistry 234, 1945-1950. 